\title{
The Deliveries Chain and Value Added in Context of Coopetition Between the Service and Industrial Companies in Poland and UE
}

\author{
Aneta Ejsmont, PhD \\ Prof. Edward F. Szczepanik
}

State School of Higher Professional Education in Suwalki, Humanistic and Economic Department,

\begin{abstract}
In an activity of companies in Poland there is a problem in expansion of the small and medium- sized enterprises which can face difficulties with their development on both the domestic and international scene in relation to big economic entities. With reference to the above, as far as a financial situation of the researched companies or more precisely their expansion is concerned we should exert every effort to make connections between small and medium- sized enterprises of service character and big economic entities which produce material products. The aim of the article is to do the analysis in relation to selected enterprises from the SME's sector which have their registered addresses in Poland and which cooperate with big companies and with the economic entities from other countries of the European Union in order to prove that the main principle is to increase expansion of the researched economic entities and that the cooperation between small and medium- sized firms and big holdings or concerns should be intensified especially when they refer to Poland and other countries of the European Union. Coopetition between the researched companies in that case should contribute to improvement in functioning of the deliveries chain and to increase in the Market Value Added (MVA) which is working out by both the small and medium- sized service enterprises and big industrial companies.
\end{abstract}

Keywords: deliveries chain, value added, company, enterprise coopetition

\section{Introduction}

The economy has never been set of micro, small, medium- sized and big enterprises which are independent of one another and which can influence other economic entities on the market only by offered supply and reported demand, as a result there are shaped prices both of services and material products. An activity of companies independently of their sizes should always support relations which are between the economic entities about servicing character and entities which produce material products. Hence also there are essential issues such as: maintenance of market relationships with suppliers, recipients and competitors and which is the most important- clients in range of making deliveries chain.

Unfortunately, in an activity of companies in Poland there is a problem of an insufficient expansion especially micro, small and medium- sized service enterprises which hinder their development both on the domestic and international arena in relation to big economic entities, which as a rule are characterized by the fact that there are usually big concerns or holdings which are geared towards the mass industrial production or even companies from SME's sector from other countries of the European Union.

That problem is important as the number and share of micro, small and medium- sized service firms in the economy is huge that their developmental dynamics should outline the dynamics of the entire economy, which could contribute to increase in the deliveries chain which are made between the service companies and industrial, too, what would also have influence on increasing the value added generated especially by the SME's sector.

To confirm the present fact, let's take into consideration Polish firms from a sector perspective in 2014 the biggest increase in number of newly registered companies took place amongst the following sections "Other service activities" (an increase about 34\%), "Transportation and storage" (about 7,4\%) and "Construction" (about 5\%). Dynamics of the number of newly 
registered entities was the lowest in the following branches: "Electricity, gas, steam and air conditioning supply" (decrease of the number of newly registered entities about half in relation to 2013) and "Water supply" and "Public administration" (decrease about one fourth). With reference to the above, a conclusion is arising that while thinking about expansion as the certain process about the social and economic character, it is worthwhile to remember that before the appearance of the so-called "global village", big industrial firms compete against one another on foreign markets, whereas companies from the SME's sector concentrate their actions on their parent markets that is in large measure on the markets of local or regional character, rarely thinking about development outside the country borders ${ }^{1}$.

Given the situation with regard to the expansion of companies in Poland and other EU countries, the differences in relation to the EU average are also present in the case of participation of individual sectors of the SME sector in the generation of gross value added according to prices of production factors .

In Poland sector of services has much lower significance than in the EU whose share in creating that value in SME's sector is about $30 \%$, while in the EU it accounts to over $41 \%$. In effect trade and industry have apparently bigger contribution in value added in Polish economy in the comparison with high-developed economies. These sectors along with the development in economy and along with service branches (on the basis of experience of the west countries) should be losing their significance. That tendency slowly sketches in Poland, especially in 2009-2011 share of companies from the industry sectors systematically decreased (from $29,7 \%$ to $29,6 \%$ ) and trade (from $27,1 \%$ to $25,8 \%$ ) in gross value added, while share of the entities from the service sector increased (from 28,0\% to 29,7\%). However the pace of these changes is slow2.

The condition of efficient defeating of these restrictions is to make connections with big companies, generally defined as cooperation between at least two entities, which in this way aspire to achieve their aims or reach a common goal on larger scale by smaller economic entities about the service character. Example of that connections in this case is coopetition defined as a process which is based on simultaneous clash with two opposing streams of relations: competition and cooperation ${ }^{3}$.

\section{Research Methodology}

In this paper an authoress used the comparative analysis and synthesis of the material as a research method. The method made it possible to prove that enhanced coopetition of the researched entitites with huge holdings and concerns from Poland as well as with economic entities from the remaining EU countries is a condition necessary to increase expansion of micro, small and medium- sized service enterprises in relation to big economic entities which produce the material products or even big concerns or holdings from other countries of the European Union to improve the innovativeness level in Polish SMS sector.

The authoress employed the method of a statistical overlap to quantify the impact of coopetition on level in expansion of smaller economic entities about service character under the account index of production (relation to the real number of produced woodworks towards a planning number) counted for the industry companies, Volume of sales Index (relation in volume of sales of an "i" article in basic period toward the volume of sales an "i" article in researched period) counted for the service companies and more precisely trade companies and height of dynamics in growth value added (relation to the relevant value towards the basic value) counted for chosen service and industry firms and created deliveries chains between them. The synthesis of the material in turn picks up separated elements to form a research problem which is the low level expansion especially of micro, small and medium-sized service enterprises in Poland. In this case synthesizing makes up a holistic cognitive treatment of the analyzed research task in the process of conducting a business activity. Therefore, this part of the research method is in particular a combination with the benchmarking of the select economic entities in terms of mentioned above indexes. This research method is complemented by comparing and contrasting results

\footnotetext{
1 Przedsiębiorczość w Polsce (2015). Warszawa: Ministerstwo Gospodarki, 39, 54

${ }^{2}$ A. Tarnawa, P. Zadura- Lichota (ed.) (2015). Raport o stanie sektora małych i średnich przedsiębiorstw w Polsce w latach 2013-2014.

Warszawa: Polska Agencja Rozwoju Przedsiębiorczości, 17

${ }^{3}$ M. Bengtsson, S. Kock (2000). Coopetition in Business Networks- Cooperate and Compete Simultaneously. "Industrial Marketing Management", vol. 29, 411; J. Cygler (2009). Kooperencja przedsiębiorstw. Czynniki sektorowe i korporacyjne. Warszawa: Szkoła Główna Handlowa w Warszawie, 15
} 
developed on the basis of data concerning generating of the value added and indexes of production and Volume of Sales Indexes reached in researched entities.

Analyzing the power of the test there are the following ranges for the standardized effect ${ }^{1}$ :

- very weak effect $(E s<0,20)$,

- weak effect $(0,20-0,50)$,

- average effect $(0,50-0,80)$,

- strong effect (Es $>0,80)$.

The comparison of the above indexes counted for determined firms provides a basis for formulation of alternative hypotheses that confirms the fact that coopetition contributes to the increase of expansion of smaller service enterprises in Poland in relation to bigger economic entities which produce the material products both from Poland and remaining countries in the EU, making it possible to verify the above hypotheses. However, it does not allow to claim with an absolute certainty that the obtained results present an optimal solution. Therefore, both the analysis and synthesis of the material is necessary.

\section{Problem in Companies Expansion}

Problem in expansion of companies especially these smaller economic entities of service character in globalizing economy is still present an it has not been sufficiently proved both in theoretical considerations and the empirical studies. Difficulty is to explicitly describe the level in expansion of service companies in relation to level in expansion of industry firms which run their economic activity both on domestic market and on area of the remaining countries from the EU, particularly because we are dealing with still changing developmental trends in the global economy. Therefore, problem in expansion of service companies in relation to big holdings or industry concerns we should consider in context of streamlining the deliveries chain which are created between service and industry firms and in context of various possibilities in increasing value added which is generated by both service companies and the ones that produce the material products. Below an authoress shows combination indexes of production counted in relation to the industry companies and turnover-counted in relation to the economic entities of service character (table 1).

Table 1. Volumes of chosen indexes counted for service and the industry companies In 2013-2014 (\%)

\begin{tabular}{|l|l|l|l|l|}
\hline \multirow{2}{*}{ Wyszczególnienie } & \multicolumn{3}{l}{ Index of production } & \multicolumn{2}{l|}{ Volume of sales Index } \\
\cline { 2 - 5 } & 2013 & 2014 & 2013 & 2014 \\
\hline EU 28 & $-0,5$ & $-1,5$ & $-0,1$ & 1,9 \\
\hline Euro area (EA-19) & $-0,7$ & $-1,5$ & $-0,8$ & 1,3 \\
\hline Belgium & 0,9 & $-4,6$ & $-0,5$ & 1,1 \\
\hline Bulgaria & $-0,1$ & $-0,9$ & 3,8 & 4,5 \\
\hline Czech Republic & 0,1 & $-0,8$ & 0,2 & 2,9 \\
\hline Denmark & 0,4 & $-2,3$ & $-1,0$ & 1,1 \\
\hline Germany & 0,2 & $-0,9$ & 0,4 & 1,6 \\
\hline Estonia & 4,2 & $-2,3$ & 1,9 & 7,1 \\
\hline Ireland & $-2,2$ & $-0,3$ & 1,0 & 4,0 \\
\hline Greece & $-3,2$ & $-0,8$ & $-8,1$ & $-0,4$ \\
\hline Spain & $-1,7$ & $-1,3$ & $-5,1$ & 1,1 \\
\hline France & $-0,7$ & $-1,3$ & 1,1 & 1,3 \\
\hline Croatia & $-2,0$ & $-2,7$ & 0,7 & $-0,4$ \\
\hline Italy & $-3,2$ & $-1,8$ & $-2,3$ & 0,4 \\
\hline Cyprus & $-13,5$ & $-3,1$ & $-6,5$ & 1,7 \\
\hline Latvia & $-0,4$ & 0,1 & 3,9 & 3,7 \\
\hline Lithuania & 3,3 & $-5,1$ & 4,4 & 5,5 \\
\hline Luxembourg & $-3,9$ & $-4,8$ & 13,4 & 8,4 \\
\hline Hungary & 1,5 & $-2,1$ & 1,8 & 5,0 \\
\hline
\end{tabular}

1 http://www.statsoft.pl/textbook/glosfra stat.html?http\%3A\%2F\%2Fwww.statsoft.pl\%2Ftextbook\%2Fglose.html (August 12, 2016) 


\begin{tabular}{|l|l|l|l|l|}
\hline Malta & $-5,3$ & $-1,2$ & $-0,5$ & $-0,4$ \\
\hline Netherlands & 0,5 & $-3,2$ & $-3,9$ & 1,0 \\
\hline Austria & 0,8 & $-1,5$ & $-0,1$ & 0,3 \\
\hline Poland & 2,3 & $-1,4$ & 4,5 & 1,1 \\
\hline Portugal & 0,5 & $-1,2$ & $-1,6$ & 1,2 \\
\hline Romania & 7,5 & 0,2 & 0,6 & 6,4 \\
\hline Slovenia & $-1,4$ & $-1,1$ & $-3,3$ & $-0,3$ \\
\hline Slovakia & 5,2 & $-3,6$ & 0,1 & 3,8 \\
\hline Finland & $-3,2$ & $-0,9$ & $-0,9$ & $-1,2$ \\
\hline Sweden & $-4,6$ & 0,1 & 2,4 & 2,4 \\
\hline United Kingdom & $-0,2$ & $-2,3$ & 1,4 & 4,2 \\
\hline Norway & $-5,0$ & 0,4 & 1,9 & 1,7 \\
\hline Switzerland & - & $-0,7$ & 1,9 & 1,0 \\
\hline Montenegro & 10,6 & - & 9,5 & 3,8 \\
\hline Serbia & 6,0 & 1,0 & $-5,5$ & 1,9 \\
\hline Turkey & 3,5 & 10,1 & 4,1 & 3,9 \\
\hline
\end{tabular}

Source: author's compilation based on Eurostat yearbook. [Online] Available: http://ec.europa.eu/eurostat/statisticsexplained/index.php/Industry_and_construction_statistics_-short-term_indicators\#Main_tables (August 12, 2016); http://ec.europa.eu/eurostat/statistics-explained/index.php/Services_statistics_-short-term_indicators\#Main_tables (August 12, 2016)

From the data included in the above table explicitly shows that in all European Union in 2013-2014 volumes of index of production counted in relation to the industry companies are lower than Volume of Sales Index counted in relation to the service companies. The other way round there are indexes noticed for Turkey, where we can see that industry has got bigger significance than services. In Poland we can clearly see improvement of both indexes, although as an authoress mentioned above, smaller significance than in the EU has got sector of services, of which share in making of that value in the SME's sector in Poland amounts to about $30 \%$, while in EU- over $41 \%$.

\subsection{Expansion of Companies in Context of Streamlining The Deliveries Chain Made Between Service and Industrial Firms}

The expansion of companies especially on the international market is a natural direction in development for Polish companies with an established position. For majority of Polish companies both industrial and service it is clear that domestic market is slowly becoming too small. A solution to this situation could be expansion on the foreign markets.

Polish entrepreneurs have already got accustomed to Ukrainian, Russian, Czech, Romanian, Slovak and Hungarian market. Now west markets of Germany, Austria and Britain make a tasty morsel for our producers of clothes, shoes or AGD make. Further destinations are United States, Canada and China. On many foreign markets, particularly in the East, Poland has got a very good brand (reputation). In countries of the former USSR our firms traditionally are associated with credibility and quality of The West. However in Asia our companies are perceived more positively and explicitly equated with the European Union. That position Polish companies hold due to keeping a high ratio of quality to price and rich collection of products. Polish companies understand needs of the rising markets and those experiencing transformation, however The West markets, which are belt- tightening, find Polish brands financially attractive products of high quality, to which British, German or Italian client became get accustomed ${ }^{1}$.

So, in the process of expansion essential role is played by an efficient deliveries chain, which generally is defined as the psychical chain, which is beginning from a supplier and ending on a last client. Both a supplier and client could be typically service or industry company. The net (snare) of deliveries chains refers to such aspects as the development of product or

\footnotetext{
${ }^{1}$ http://nf.pl/przedsiebiorca/ekspansja-polskich-przedsiebiorstw-na-rynki-zagraniczne ,14603,220 (August 18, 2016)
} 
service, purchasing, production, psychical distribution and the after- sales services and deliveries which are realized by outside tenderers, too 1 .

Good functioning of the deliveries chain should be an efficient and effective system which acts in practice, which could make the value added for all participants on its entire lengths. That system is responsible for coordination of the flow of the material goods, services and information connected with them.

The system has got influence in costs minimization of that flow and condition of service which consists in delivering the right goods or services to a right client in the right place, time, quantity and price. The deliveries chain participate in assuring the usefulness ${ }^{2}$

- place by transferring goods and services, where there is demand on them,

- time by holding the right level of stocks and distribution of the material goods or services.

Many difficulties could come into being in growing longer deliveries chains which are made between the industry and service firms, such as ${ }^{3}$ :

- cultural changeability, especially when companies try to develop their expansion outside country borders ,

- different levels of the intellectual capitals,

- diversified, oftentimes contradictory systems of value,

- lack of direct contacts,

- changeable religious, political, law, social and economic systems,

- diverse degree of tendency to the virtual group work,

- different understanding of confidence,

- diversified level of transformations in technique and technology of the 21th century,

- diversified level of expenditures on research and development.

With reference to the above, efficient and effective functioning of the deliveries chain depends on in the main measuring cup possibilities in defeating of above mentioned barriers, which connect with constant making decisions both about strategic and operational character. It concerns such issues here as 4 :

- describing of the essential competences and choice in strategies of the deliveries chain,

- adapting all deliveries chain to nature of demand and supply,

- drawing up general concept in deliveries chain however it concerns combinations in functions and processes,

- describing scope and degree of outsourcing, where service companies provide different kind services for big holdings or concerns of industry character,

- choice of deliveries and intermediaries in distribution,

- designing of system in flow of raw materials, materials and etc.,

- choice in the concept of management of stocks,

- decisions about the computer system, referring the flow of information,

- choice of rules or model in management of risk in the deliveries chain,

- decisions about relations between participants of the chain,

- choice of the way in costs management ,

- choice of localization of a company,

- formulating rules in management of transport and etc.

All the decisions made by entrepreneurs both that run of the service and industry firms in frames created between that economic entities deliveries chain as a rule should increase their competitiveness. We should in addition consider the fact that taking off notion "competition" and "delivery chain" we could distinquish the following situations ${ }^{5}$ : 
- competition between the deliveries chains,

- competition of the deliveries chains, which aim at changing the position of a company without changing the structure of chain,

- competition of deliveries chains, which aim at changing the structure of the chain and building a new one.

With reference to above dissertations we should confirm that notion of deliveries chain refers to chains of firms which are deliveries and receivers, where the service companies could play roles of deliveries of services for the industry companies which in this case are receivers. So, right planning of the deliveries chain in the contemporary world is one of essential challenges which a company is making when it wants to plan expansion on the international scale. That firm must take into consideration not only the geographical factors or development of the transport infrastructure in defined country, but the political factors, fiscal system and customs barriers. One of the possibilities which could allow the significant restrictions in costs is for example relocation of a manufacture to a country of the main receiver. Other challenge is to trade with countries with embargo. The Russian embargo extorted on Polish importers and exporters change the trade politics. One of the solutions which are more popular is so- called cross- trade. It consists on purchasing by a Polish importer goods in Asia and next it sells these goods for Russian entities during direct sea transport to Russia. It is a good solution as an authoress of the present article mentioned in the introduction, to expansion in Poland, however internationally the most chances have big industry companies, because service firms are still afraid of new challenges which could aim towards globalization. Meanwhile, in other countries of the European Union situation is almost opposite.

\subsection{Problem in Increasing The Value Added by Service and Industry Companies}

The last element in deliveries chain in a scheme which describes different sector connections which are present between service and industry companies is so- called value added. A company is able to create the value added if the profitability of capital is higher than the weighted average cost of the capital. The cost of the capital makes minimal profit margin expected from invested capital by investors. It depends on current value of future cash flows generated by a company, which sets his economic value. The right decision- making criterion and index of an assessment of the results in a company from point of view maximizing of the value is so- called market value added. First time the concept of the Market Value Added was presented by Bennett Steward at the beginning of the nineties ${ }^{6}$.

With reference to the above, using of MVA index means that it denotes not only more complex assessment of the results in activity of a company, but it is above all symptom in new approach to a way of management of a company accordingly

\footnotetext{
${ }^{1}$ E. Bendoly, N. Craig, N. DeHoratius (2016). Consistency and Recovery in Retail Supply Chains, 4-6. [Online] Available: http://ssrn.com/abstract=2757134 (June 28, 2016)

${ }^{2}$ A. Szymonik (2011). Logistyka i zarządzanie łańcuchem dostaw, Część 1. Warszawa: Wydawnictwo Difin, 183

${ }^{3}$ A. Szymonik (2011). Logistyka i zarządzanie łańcuchem dostaw, Część 1. Warszawa: Wydawnictwo Difin, 185

${ }^{4}$ M. Ciesielski (2009). Łańcuchy dostaw.In M. Ciesielski (Eds.), Instrumenty zarządzania łańcuchami dostaw (pp. 18-19). Warszawa: Polskie Wydawnictwo Ekonomiczne

${ }^{5}$ M. Ciesielski (2009). Łańcuchy dostaw. In M. Ciesielski (Eds.), Instrumenty zarządzania łańcuchami dostaw (pp. 18-19). Warszawa: Polskie Wydawnictwo Ekonomiczne; L. Ouabouch (2015), Ten Revolitionary Supply Chain Management. Strategies for Sustainable Competitive Advantage, 12-13. [Online] Available: http://ssrn.com/abstract=2679048 (November 5, 2015)

${ }^{6}$ G. B. Stewart (1991). The Quest for Value. The EVA TM Management Guide. New York: Harper Business, 168; J. H. Block, F. Spiegel (2013). Family Firm Density and Regional Innovation Output: An Exploratory Analysis. Journal of Family Business Strategy, Vol. 4, No. 4,273
} 
with the criterion in maximization benefits by investors. Surplus in market value of a company $(\mathrm{V})$ over value invested in a company capital (K) is defined as market value added (MVA). What we could describe by the following pattern':

\section{$M V A=V-K a$, where, $M V A>0$}

where:

MVA - market value added,

$\mathrm{V}$ - surplus of the market value in a company,

$\mathrm{Ka}$ - value of invested capital in a company.

MVA could assume negative or positive values, which from investors' point of view means profits or losses from investments in shares of that company. If a company creates the value added of invested capital so the added value (MVA) reached by them is positive. If invested capital in a company loses on volume the market value added will be negative for that company².

The market value added is the best measure of the real company success which is seen in the growth of the prices of their products or services. It mainly depends on assessment of future results of a company activity. Typically small and mediumsized enterprises from Poland, in fear of debilitating their position on markets, are afraid of expansion on the international markets, not realizing that in this way they generate much lower the market value added than it would take place in case of entering on wide scale on the international markets. The industry companies are less willful on expansion, although real contribution of the economic entities from foremost countries of the European Union is higher in making of the market value added than of the industry companies from Poland which will be proved in paragraph which will be devoted to the empirical analysis of coopetition between the service and industry companies.

\section{Process of Coopetition Between The Service And Industry Companies}

In the deliveries chain which is made between small and medium- sized service enterprises and big firms which produce the material goods essential role should be played by partnership which in praxeology takes its origin from cooperate, that is in a word- from activities which are carried out in two stages, whose entities are busy with something. It is betting in this case three possible common situations: cooperation, indifference or counteracting, depending on the aim of an activity it could have the form of agreement, contradiction or disagreement. We could accept that described small or medium- sized firm cooperate with a big economic entity of industry character then and only then when the causative behavior in a service company impacts on results of the causative behavior in a big industry firm or when action of that company in a similar way impacts on result in action of the lower size economic entity of the service character. Cooperation understood in this way takes both positive and negative sides, because this phenomenon is inseparably accompanied by competing between one another, too ${ }^{3}$.

So, both theory and practice show if level of competitive and cooperative is basis to create a model of coopetition in both service and industry companies. With reference to above dissertations, intensity of appearing of the coopetitive relations is

\footnotetext{
${ }^{1}$ A. Duliniec (2001). Struktura i koszt kapitału w przedsiębiorstwie. Warszawa: Wydawnictwo Naukowe PWN, 146-147

${ }^{2}$ A. Duliniec (2001). Struktura i koszt kapitału w przedsiębiorstwie. Warszawa: Wydawnictwo Naukowe PWN, 150-151

${ }^{3}$ A. Szymonik (2011). Logistyka i zarządzanie łańcuchem dostaw, Część 2. Warszawa: Wydawnictwo Difin, 56
} 
depended on intensity in the competitive and coopetitive relations between representatives in small and medium sized service enterprises and big industry corporations both on the domestic and international market.

\subsection{Theoretical Premise In Process of Coopetition}

Intensity of competitive relations on so- called "the international arena" is connected with their frequency between members of the structure in relation to general number of available competitive connections. We could express that by the following pattern':

$$
I K=\frac{\sum_{i=1}^{K} \sum_{j=1}^{K} \text { CRKij }}{\mathrm{N}}+E x, \text { gdzie } i<j ;
$$

where:

IK - intensity of competition between the service and industry companies,

$\mathrm{K}$ - number of competitors,

$\mathrm{i}, \mathrm{j}$ - constant parameters,

CRK - frequency in the coopetitive relations,

$\mathrm{N}$ - number of the coopetitive relations between small and medium- sized service enterprises and big economic entities about industry character,

Ex - level in export of the service and industry companies which compete on the international market.

Intensity of cooperation makes function in frequency in making the cooperative agreements in relation to general number of available connections between partners on so- called "the international arena", which we could express by the following pattern:

$$
I C O O P=\frac{\sum_{i=1}^{K} \sum_{j=1}^{K} C O O P i j}{\mathrm{M}}+E x, \text { gdzie } i>j
$$

gdzie:

ICOOP - intensity of cooperation between the service and industry companies,

$\mathrm{K}$ - number of cooperators,

$\mathrm{i}, \mathrm{j}$ - constant parameters,

COOP - frequency of cooperative relations,

$\mathrm{M}$ - number of the cooperative relations between small and medium- sized service enterprises and big economic entities about industry character,

Ex - level in export of the service and industry companies which cooperate on the international market.

from here ${ }^{3}$ :

$I K C O O P=\frac{\sum_{i=1}^{K} x \sum_{j=1}^{K} x C R K i j}{\sum_{i=1}^{K} x \sum_{j=1}^{K} x C O O P i j}+E x$ 
where:

IKCOOP - intensity of coopetition

Summing up we should state that the service entrepreneurs from the SME's sector who decide on cooperation and competition simultaneously with economic entities from remaining countries of the EU and domestic big industry concerns or holdings perceive their own interdependence by the prism of both financial and technological benefits. The character of the international coopetition points out that it is compound arrangement, investigating both in vertical and horizontal arrangement. In that aim entrepreneurs both service and produce their products in their activity, however entrepreneurs from the SME's sector of service character should gain a strategy of the vertical international coopetition which relies on the technological connection in production and distribution of sale or other processes connected with functioning and competing of firms both on domestic and international market ${ }^{4}$. However, process of the horizontal coopetition relies on merging under control so- called "integrator" of the entities which serve similar function in canal of the both domestic and international market ${ }^{5}$.

\subsection{The Empirical Analysis of Coopetition Process}

In the empirical analysis of coopetition process between small or medium- sized service enterprises and big industry firms is essential to precisely emphasize what we understand by notion of services in the industry system. So, service is a free action which one company could offer to other company, which is nontangible. Services in itself differ in relation to whether they are based on work of appliance or on work of people. Some services demand attendance of clients and some services not. Moreover, services differ in relation to whether they satisfy needs of natural persons (services for natural persons) or needs of firms (services for firms). Contractors have different aims of their actions and represent different forms of property 6 .

The management of production refers mainly to issues which concern designing of industry systems, organization of industry processes, their planning and controlling. In management of production we could set two deciding levels?:

- the strategic level, where on this level companies taking actions concern designing of the industry system and describing strategies in future action and

- the operational level, on which companies describing actions concern with functioning of the industry system, here is described structure and flows in processes in designed system.

With reference to the above, the industry system intentionally is a designed and organized material arrangement, It is anenergetic and informational system which is exploited by a man. It serves to produce determined products in aim to satisfying diverse needs of clients. So, sector of companies both service and industry has got significant share in generating

\footnotetext{
1 J. Cygler (2009). Kooperencja przedsiębiorstw. Czynniki sektorowe i korporacyjne. Warszawa: Szkoła Glówna Handlowa w Warszawie, 41

2 J. Cygler (2009). Kooperencja przedsiębiorstw. Czynniki sektorowe i korporacyjne. Warszawa: Szkoła Główna Handlowa w Warszawie, 42

${ }^{3}$ Opracowanie własne na podstawie author's compilation based on J. Cygler (2009). Kooperencja przedsiębiorstw. Czynniki sektorowe i korporacyjne. Warszawa: Szkoła Główna Handlowa w Warszawie, 42

${ }^{4}$ A. Ejsmont (2012). Wpływ kooperacji na rozwój firm rodzinnych w Polsce (na przykładzie E- Energo S.A.). In Ł. Sułkowski (Eds.), Firmy rodzinne- współczesne wyzwania przedsiębiorczości rodzinnej (pp. 361-364). Łódż: Wydawnictwo Społecznej Akademii Nauk

${ }^{5}$ B. Westbrock (2012), Horizontal Integration in Markets for Complementary Components and Vertical Product Differentiation: A Case-

Based Analysis in The Semiconductor Industry, 10. [Online] Available: http://papers.ssrn.com/sol3/papers.cfm?abstract id=637641 (February 5, 2012)

${ }^{6}$ D. Burchart- Korol, J. Furman (2007). Zarządzanie produkcją i usługami. Gliwice: Wydawnictwo Politechniki Śląskiej, 20-21

${ }^{7}$ D. Burchart- Korol, J. Furman (2007). Zarządzanie produkcją i usługami. Gliwice: Wydawnictwo Politechniki Śląskiej, 27
} 
the value added. The following figure shows data concerning index dynamics in growth of the value added in all the European Union in 2004-2014 (figure 1).

Figure 1. Market Value Added in EU-28, 2004-2014 (\%)

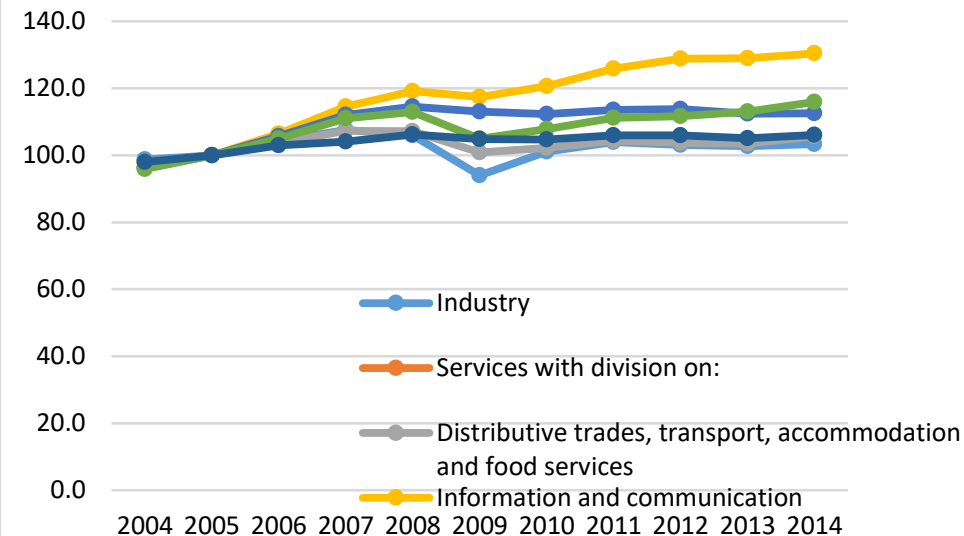

Source: author's compilation based on Eurostat yearbook. [Online] Available: $h$ ttp://ec.europa.eu/eurostat/statisticsexplained/index.php/National_accounts_and_GDP\#Main_tables (August 25, 2016).

It results from analysis of the above data that structural change is, at least in part, a result of phenomena such as technological change, developments in relative prices, outsourcing and globalization, often resulting in manufacturing activities being moved to lower labour- cost regions, both within and outside the EU. Several activities were particularly affected by the financial and economic crisis and its aftermath. Industry experienced the sharpest contraction between 2007 and 2009, value added in the EU- 28 falling overall by $12,6 \%$ (in volume terms). EU- 28 industrial output fell by a further 1,2\% between 2011 and 2013. Business services as well as distributive trades, transport, accommodation and food services also experienced relatively strong falls in value added in $2009-7,1 \%$ and $6,0 \%$ respectively. Distributive trades, transport, accommodation and food services recorded two further, smaller contractions in output in 2012 and 2013. Smaller reductions in value added were experienced for other activities during the crisis, most notably in 2009, 2010 and 2013 for financial and insurance services and for arts, entertainment, recreation and other services. From the point of view of market value added which is generated by companies from individual countries of The European Union this what meaning seems material for EU have got services and industry. That situation confirm data entered into below table (table 2).

Table 2. Market Value Added at basic prices, comparable 2003 and 2013 (\%)

\begin{tabular}{|c|c|c|c|c|c|c|c|c|c|c|c|c|}
\hline \multirow[t]{3}{*}{ Countries } & \multirow{2}{*}{\multicolumn{2}{|c|}{ Industry }} & \multicolumn{10}{|c|}{ Services with division on } \\
\hline & & & \multicolumn{2}{|c|}{$\begin{array}{l}\text { Distributive } \\
\text { trades, transport, } \\
\text { accommodation } \\
\text { and food } \\
\text { services }\end{array}$} & \multicolumn{2}{|c|}{$\begin{array}{l}\text { Information and } \\
\text { communication }\end{array}$} & \multicolumn{2}{|c|}{$\begin{array}{l}\text { Financial and } \\
\text { insurance } \\
\text { activities }\end{array}$} & \multicolumn{2}{|c|}{$\begin{array}{l}\text { Professional, } \\
\text { scientific, } \\
\text { technical, } \\
\text { administrative } \\
\text { and support } \\
\text { services }\end{array}$} & \multicolumn{2}{|c|}{$\begin{array}{l}\text { Arts, enter- } \\
\text { tainment and } \\
\text { recreation; } \\
\text { other services }\end{array}$} \\
\hline & 2003 & 2013 & 2003 & 2013 & 2003 & 2013 & 2003 & 2013 & 2003 & 2013 & 2003 & 2013 \\
\hline EU-28 & 20,3 & 19,1 & 19,7 & 19,0 & 5,0 & 4,5 & 5,3 & 5,5 & 9,7 & 10,4 & 3,4 & 3,6 \\
\hline $\begin{array}{l}\text { Euro area (EA- } \\
18)\end{array}$ & 20,6 & 19,3 & 19,6 & 18,8 & 4,6 & 4,2 & 5,0 & 5,1 & 9,7 & 10,4 & 3,5 & 3,7 \\
\hline Belgium & 19,9 & 15,6 & 20,5 & 19,8 & 4,1 & 4,1 & 5,9 & 6,5 & 11,4 & 13,2 & 2,0 & 2,1 \\
\hline Bulgaria & 23,2 & 25,2 & 22,2 & 19,5 & 4,2 & 5,4 & 4,2 & 7,2 & 3,9 & 5,6 & 1,2 & 2,4 \\
\hline Czech Republic & 29,3 & 31,8 & 22,5 & 19,2 & 4,7 & 4,7 & 3,3 & 4,4 & 6,5 & 6,8 & 2,6 & 2,4 \\
\hline
\end{tabular}




\begin{tabular}{|c|c|c|c|c|c|c|c|c|c|c|c|c|}
\hline Denmark & 19,6 & 16,9 & 20,2 & 19,7 & 4,5 & 4,2 & 5,4 & 6,5 & 6,6 & 8,9 & 3,4 & 3,5 \\
\hline Germany & 24,5 & 25,5 & 16,2 & 14,5 & 4,0 & 3,9 & 4,9 & 4,1 & 11,1 & 11,4 & 4,5 & 4,6 \\
\hline Estonia & 22,4 & 21,5 & 24,9 & 23,2 & 4,9 & 4,9 & 3,8 & 3,2 & 6,4 & 8,0 & 2,7 & 2,4 \\
\hline Ireland & 27,3 & 26,3 & 16,2 & 15,6 & 6,2 & 9,0 & 9,4 & 10,1 & 6,5 & 8,7 & 1,8 & 2,1 \\
\hline Greece & 12,6 & 14,6 & 30,3 & 22,7 & 4,1 & 4,5 & 4,3 & 4,8 & 3,8 & 4,6 & 3,7 & 4,9 \\
\hline Spain & 19,0 & 17,5 & 23,6 & 25,9 & 4,6 & 4,0 & 4,8 & 3,9 & 6,4 & 7,8 & 3,6 & 3,8 \\
\hline France & 16,2 & 12,8 & 18,8 & 18,2 & 5,2 & 4,2 & 4,3 & 5,0 & 11,4 & 12,4 & 3,3 & 3,4 \\
\hline Croatia & 21,6 & 21,0 & 23,2 & 20,7 & 5,1 & 4,8 & 5,7 & 6,7 & 5,5 & 7,5 & 2,4 & 2,7 \\
\hline Italy & 20,8 & 18,3 & 21,1 & 20,8 & 4,8 & 3,9 & 4,9 & 5,5 & 8,8 & 8,8 & 3,2 & 3,8 \\
\hline Cyprus & 11,9 & 8,7 & 24,1 & 24,3 & 4,6 & 4,5 & 5,9 & 10,2 & 5,7 & 7,6 & 3,8 & 4,2 \\
\hline Latvia & 17,6 & 18,7 & 30,5 & 29,1 & 5,6 & 4,4 & 3,5 & 3,7 & 5,4 & 7,0 & 2,8 & 2,6 \\
\hline Lithuania & 24,2 & 24,5 & 28,4 & 33,2 & 5,0 & 3,1 & 1,7 & 2,4 & 4,7 & 5,6 & 2,4 & 1,8 \\
\hline Luxembourg & 11,7 & 5,9 & 17,7 & 17,6 & 5,8 & 6,2 & 23,2 & 25,4 & 8,0 & 10,9 & 1,8 & 2,0 \\
\hline Hungary & 25,2 & 26,0 & 17,2 & 17,6 & 5,0 & 5,1 & 4,1 & 4,9 & 7,5 & 8,4 & 3,0 & 2,9 \\
\hline Malta & 19,6 & 12,8 & 25,4 & 21,0 & 4,8 & 6,4 & 5,7 & 8,1 & 8,3 & 10,8 & 4,0 & 9,9 \\
\hline Netherlands & 18,2 & 19,7 & 20,2 & 18,6 & 5,3 & 4,5 & 7,3 & 8,7 & 10,7 & 10,9 & 2,6 & 2,6 \\
\hline Austria & 22,8 & 21,7 & 22,7 & 21,9 & 3,8 & 3,2 & 5,2 & 5,0 & 7,6 & 9,1 & 2,7 & 2,9 \\
\hline Poland & 23,5 & 24,7 & 25,4 & 27,3 & 4,4 & 3,5 & 4,2 & 4,3 & 6,3 & 7,2 & 3,6 & 3,1 \\
\hline Portugal & 19,0 & 18,9 & 23,0 & 25,4 & 3,8 & 3,6 & 6,2 & 5,8 & 5,7 & 6,5 & 2,4 & 2,9 \\
\hline Romania & 27,8 & 34,3 & 19,0 & 12,5 & 4,8 & 3,9 & 2,1 & 2,5 & 3,4 & 7,0 & 2,4 & 3,4 \\
\hline Slovenia & 28,2 & 25,7 & 19,4 & 20,6 & 3,8 & 4,5 & 4,5 & 4,1 & 8,4 & 9,0 & 2,9 & 2,7 \\
\hline Slovakia & 28,7 & 26,7 & 22,4 & 22,8 & 3,9 & 4,5 & 3,8 & 4,1 & 5,6 & 7,7 & 2,2 & 3,4 \\
\hline Finland & 26,5 & 18,7 & 17,9 & 17,0 & 5,4 & 5,2 & 2,4 & 2,5 & 5,9 & 8,4 & 2,7 & 3,3 \\
\hline Sweden & 22,8 & 18,8 & 17,3 & 17,5 & 5,3 & 5,4 & 4,1 & 4,9 & 7,6 & 9,9 & 2,8 & 3,1 \\
\hline United Kingdom & 17,6 & 14,3 & 19,8 & 18,5 & 7,1 & 6,6 & 6,8 & 7,8 & 11,5 & 12,5 & 3,4 & 3,5 \\
\hline Iceland & 15,7 & 19,8 & 16,7 & 17,1 & 5,4 & 4,1 & 8,0 & 6,5 & 6,4 & 6,9 & 2,5 & 2,7 \\
\hline Norway & 33,2 & 34,6 & 16,7 & 12,8 & 4,2 & 3,4 & 4,0 & 5,2 & 5,5 & 7,4 & 2,4 & 1,9 \\
\hline Switzerland & 20,9 & 20,8 & 22,0 & 21,9 & 4,3 & 3,9 & 12,0 & 11,1 & 7,2 & 8,5 & 8,7 & 8,8 \\
\hline Montenegro & - & 12,4 & - & 27,6 & - & 5,9 & - & 4,9 & - & 4,5 & - & 2,3 \\
\hline $\begin{array}{l}\text { FYR of } \\
\text { Macedonia17,5 }\end{array}$ & - & 17,8 & - & 21,6 & - & 4,0 & - & 3,4 & - & 3,7 & - & 2,6 \\
\hline Serbia & 23,6 & 25,3 & 15,2 & 17,5 & 4,6 & 5,8 & 3,2 & 3,7 & 3,0 & 6,4 & 2,1 & 2,5 \\
\hline Turkey & 23,4 & 21,6 & 29,1 & 29,9 & 2,5 & 2,2 & 3,8 & 3,8 & 4,0 & 5,8 & 1,9 & 1,6 \\
\hline
\end{tabular}

Source: Eurostat yearbook. [Online] Available: http://ec.europa.eu/eurostat/statistics-
explained/index.php/National_accounts_and_GDP\#Main_tables (August 25, 2016)

Data entered into table 3 give an overview of the relative importance of 6 activities in terms of their contribution to gross value added. Between 2003 and 2013, industry's share of EU-28 value added fell 1,2 percentage points to 19,1\%, remaining just ahead of distributive trades, transport, accommodation and food services (19,0\%) which also recorded a fall in its share, down 0,7 percentage points during these 10 years. The next largest activities in 2013 were real estate activities $(11,2 \%)$, followed by professional, scientific, technical, administrative and support services (hereafter, business services) $(10,4 \%)$, financial and insurance services $(5,5 \%)$ and information and communication services $(4,5 \%)$. The smallest contributions came from entertainment and other services (3,6 \%). Services contributed $73,6 \%$ of the EU-28's total gross value added in 2013 compared with $71,5 \%$ in 2003. The relative importance of services was particularly high in Luxembourg, Cyprus, Malta, Greece, France (2012 data), the United Kingdom, Belgium and Denmark where they accounted for more than three quarters of total value added.

The data shows that market value addend generated by the service sector in Poland clearly is lower than that of countries such as Luxembourg, Cyprus, Malta, Greece or France and both in 2003 and 2013. As we are talking about the value added generated in industry both in 2003 and 2013 Poland is overtaken by such countries as Romania, Slovenia or Slovakia. Unprofitable results for all sector of companies in Poland in the comparison with the union average are put into results in the individual presentation. Gross value added according to prices of the production factors in converting into one company in Poland is lower than in EU. Particularly unprofitable situation concerns microenterprises which are typically service ones (gross value added made by a microenterprise in Poland makes just under one third of value her counterpart in EU). An average Polish usually service and industry big firm can generate the gross value added on level less than half 
of the result in the union company. Only in cases of small service enterprises whose value makes over half of the value added in an average company of the category in the EU, which is presented in the following figure (figure 2).

Figure 2. Index of dynamics in growth of value addend generated by companies in Poland in 2004-2012

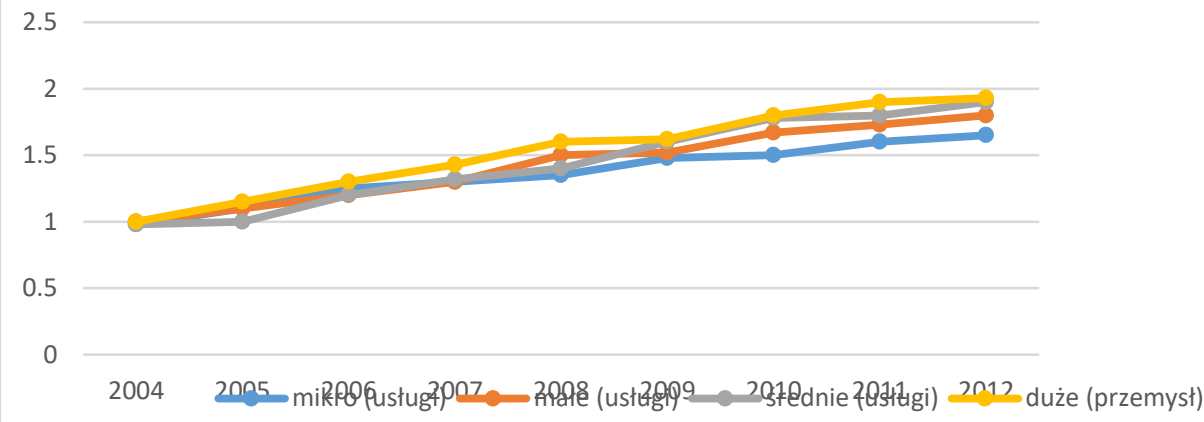

Source: author's compilation based on P. Zadura- Lichota, A. Tarnawa (Eds) (2014). Raport o stanie sektora małych i średnich przedsiębiorstw w Polsce w latach 2012-2013. Warszawa: Polska Agencja Rozwoju Przedsiębiorczości, 16

Based on the above data one should explicitly state, that over a distance 2004-2012 we could clearly observe growing tendencies of companies in Poland which are confirmed above all by increasing of index of dynamics in growth of value addend noticed amongst big industry companies at simultaneous decrease of share smaller firms (microenterprises of the service character). In all researched period an increase in meaning of big industry firms was observed, of which share in creating of the value added is significant. In case of medium- sized and small service enterprises it is hard to show tendencies clearly, their share in making of the market value added in 2009-2012 hesitates for medium- sized enterprises on level from 1,6 to 1,9 and in case of small- from 1,52 to 1,8. In group micro enterprises in 2009-2012 we observe decreasing tendency (from 1,48 in 2009 to 1,65 in 2012).

With reference to the above, gross value addend made by companies in Poland increases ceaselessly from 2005 in all groups of firms. In 2012 only in case of small enterprises we noticed jaunty slowing down of that growth, although as an authoress mentioned below, gross value added according to prices of the production factors in converting into one company in Poland is lower than in EU. Particularly unprofitable situation concerns microenterprises (gross value added made by a microenterprise in Poland makes just under one third of value her counterpart in EU). An average Polish service and industry big firm can generate the gross value added on level less than half of result in the union company. Only in case of small enterprises that value makes over half of the value added in an average company that category in EU ${ }^{1}$. It means that micro-, small and medium- sized service enterprises cooperate with one another only to a small degree, trying only to compete in terms of prices and quality of services offered. Only big firms have got more respect towards one another, there are noticeable aspects of cooperation with elements of coopetition.

Therefore, in this case it is advisable for smaller economic entities of service character to cooperate with big industry holdings or concerns where the deliveries chains not excluding of course elements of competitiveness are made more efficient. With reference to above dissertations taking into attention data concerning index of dynamics in growth of value added noticed in 2004-2012 amongst micro, small, medium- sized and big enterprises from Poland and other countries of EU an authoress is trying to study impact of coopetition on expansion of smaller economic entities of service character, using program Statistica made t-student test (t-test) for dependent samples. This data is shown in the following figure (figure $3)$.

${ }^{1}$ A. Tarnawa, P. Zadura- Lichota (Eds) (2015). Raport o stanie sektora małych i średnich przedsiębiorstw w Polsce w latach $2013-2014$. Warszawa: Polska Agencja Rozwoju Przedsiębiorczości, 17 
Figure 3. Relation of the standardized effect from height of index dynamics in growth value addend noticed amongst micro, small and medium- sized service enterprises and big industry companies in 2004-2012

00000

Dependent Sample t-Test: Sample Size Calculation

Two Means, t-Test, Dep. Samples (H0: Mu1 = Mu2)

$\mathrm{N}$ vs. Es (Alpha $=0,05$, Power Goal $=0,8$ )

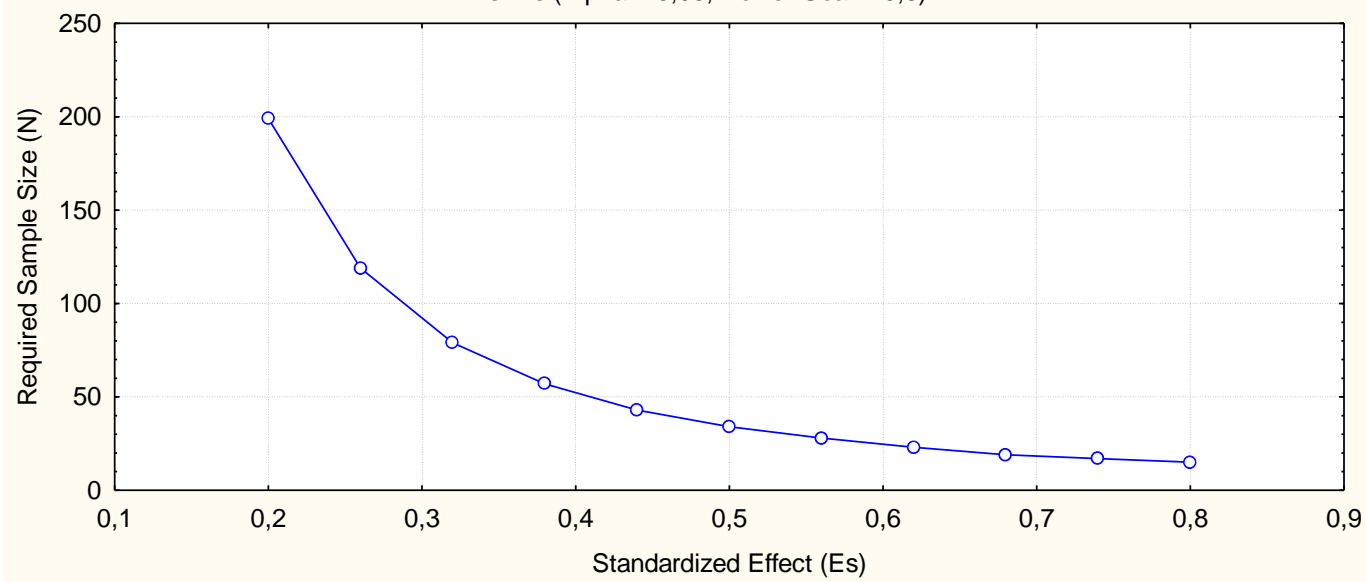

Source: author's compilation based on P. Zadura- Lichota, A. Tarnawa (Eds) (2014). Raport o stanie sektora małych i średnich przedsiębiorstw w Polsce w latach 2012-2013. Warszawa: Polska Agencja Rozwoju Przedsiębiorczości, 16

In context of the statistical gravity an authoress formulated hypothesis saying that the fact that coopetition does not impact increase in the economic expansion of smaller economic entities of service character in Poland in relation to companies of the same size from foremost countries of the EU, which is opposite to what an authoress would like to demonstrate. In an analyzed case the standardized effect in the height $-0,1128$ and the critical value $t=1,9638$ and actual power for required $\mathrm{N}$ going for 0,8002 confirms credibility of the alternative hypothesis saying that the condition in an increase of expansion of the researched companies is heightened coopetition between economic entities as in that case recommended is coopetition between the smaller firms of service character and big holdings or concerns produced the material products, where efficient deliveries chains are made, too.

\section{Summary}

In activity of companies from Poland appears problem of insufficient expansion especially of micro, small and mediumsized enterprises, which hinders their development both on the domestic and international arena in relation to the big economic entities, which as a rule are characterized by the fact that they are usually big concerns or holdings which are geared towards the mass industrial production. That problem concerns the issue of expansion of Polish companies in relation to the economic entities from other countries of the European Union.

To defeat these restrictions efficiently coopetition is necessary. It is defined as a process which relies on simultaneous clash of two opposing streams of relations: competition and cooperation. To prove this, in the article an authoress performed the comparative analysis on basis of the index of production (relation of the real number of produced woodworks to planning number) counted for the industry companies, Volume of sales Index (relation of the volume of sales of an "i" article in basic period to volume of sales an " $i$ " article in researched period) counted for the service companies and more precisely trade companies and height of dynamics in growth value added (relation the relevant value towards to basic) counted for chosen service and industry firms and deliveries chains created between them.

Taking into consideration the index of production, in all the European Union in 2013-2014 volumes of present index counted in relation to the industry companies are lower than Volume of Sales Index counted in relation to the service companies. 
On the basis of that last index an authoress was trying to describe (with t- student test's for dependent samples) an impact of coopetition on growth of expansion micro-, small and medium- sized service enterprises on the international area. Here also an authoress made comparison level of Polish companies in relation to the economic entities from other countries of the European Union. In context of testing of the statistical gravity an authoress formulated result that condition in an increase of expansion of the researched companies is heightened coopetition between the smaller firms of service character and big holdings or concerns produced the material products, where efficient deliveries chains are made, too.

\section{Bibliography}

[1] Bendoly E., Craig N., DeHoratius N. (2016). Consistency and Recovery in Retail Supply Chains. [Online] Available: http://ssrn.com/abstract=2757134 (June 28, 2016).

[2] Bengtsson M., Kock S. (2000). Coopetition in Business Networks- Cooperate and Compete Simultaneously. "Industrial Marketing Management", vol. 29.

[3] Block J. H., Spiegel F. (2013). Family Firm Density and Regional Innovation Output: An Exploratory Analysis. Journal of Family Business Strategy, Vol. 4, No. 4.

[4] Burchart- Korol D., Furman J. (2007). Zarządzanie produkcją i usługami. Gliwice: Wydawnictwo Politechniki Ślaskiej.

[5] Ciesielski M. (2009). Łańcuchy dostaw. In Ciesielski M. (Eds.), Instrumenty zarządzania łańcuchami dostaw. Warszawa: Polskie Wydawnictwo Ekonomiczne.

[6] Cygler J. (2009). Kooperencja przedsiębiorstw. Czynniki sektorowe i korporacyjne. Warszawa: Szkoła Główna Handlowa w Warszawie.

[7] Duliniec A. (2001). Struktura i koszt kapitału w przedsiębiorstwie. Warszawa: Wydawnictwo Naukowe PWN.

[8] Ejsmont A. (2012). Wpływ kooperacji na rozwój firm rodzinnych w Polsce (na przykładzie E- Energo S.A.). In Ł. Sułkowski (Eds.), Firmy rodzinne- współczesne wyzwania przedsiębiorczości rodzinnej. Łódź: Wydawnictwo Społecznej Akademii Nauk.

[9] Ouabouch L. (2015), Ten Revolitionary Supply Chain Management. Strategies for Sustainable Competitive Advantage. [Online] Available: http://ssrn.com/abstract=2679048 (November 5, 2015).

[10] Przedsiębiorczość w Polsce (2015). Warszawa: Ministerstwo Gospodarki.

[11] Stewart G. B. (1991). The Quest for Value. The EVA TM Management Guide. New York: Harper Business.

[12] Szymonik A. (2011). Logistyka i zarządzanie łańcuchem dostaw, Część 1. Warszawa: Wydawnictwo Difin.

[13] Szymonik A. (2011). Logistyka i zarządzanie łańcuchem dostaw, Część 2. Warszawa: Wydawnictwo Difin.

[14] Tarnawa A., Zadura- Lichota P. (ed.) (2015). Raport o stanie sektora małych i średnich przedsiębiorstw w Polsce w latach 2013-2014. Warszawa: Polska Agencja Rozwoju Przedsiębiorczości.

[15] Westbrock B. (2012), Horizontal Integration in Markets for Complementary Components and Vertical Product Differentiation: A Case- Based Analysis in The Semiconductor Industry. [Online] Available: http://papers.ssrn.com/sol3/papers.cfm?abstract_id=637641 (February 5, 2012).

[16] Zadura- Lichota P., Tarnawa A. (Eds) (2014). Raport o stanie sektora małych i średnich przedsiębiorstw w Polsce w latach 2012-2013. Warszawa: Polska Agencja Rozwoju Przedsiębiorczości.

[17] http://ec.europa.eu/eurostat/statistics-explained/index.php/Industry_and_construction_statistics_-_shortterm_indicators\#Main_tables (August 12, 2016).

[18] http://ec.europa.eu/eurostat/statistics-explained/index.php/National_accounts_and_GDP\#Main_tables (August 25, 2016).

[19] http://ec.europa.eu/eurostat/statistics-explained/index.php/Services_statistics_-_short-term_indicators\#Main_tables (August 12, 2016).

[20] http://nf.pl/przedsiebiorca/ekspansja-polskich-przedsiebiorstw-na-rynki-zagraniczne,,14603,220 (August 18, 2016). 
[21] http://www.statsoft.pl/textbook/glosfra stat.html?http\%3A\%2F\%2Fwww.statsoft.pl\%2Ftextbook\%2Fglose.html (August 12, 2016). 
